Acta Theriologica 37 (4): $371-380,1992$.

PL ISSN $0001-7051$

\title{
Relative growth and annual size variation in Crocidura russula from the Ebro Delta, Spain
}

\author{
Mª José LÓPEZ-FUSTER and Jacint VENTURA
}

\begin{abstract}
L6pez-Fuster M. J. and Ventura J. 1992. Relative growth and annual size variation in Crocidura russula from the Ebro Delta, Spain. Acta theriol. 37: 371 - 380.

We report data on the somatometry of the white-toothed shrew Crocidura russula (Hermann, 1780), based on 302 specimens (153 males, 149 females) captured between 1980 and 1982 in the Ebro Delta (northeastern Spain). Variations in body size and weight were analysed according to sex, relative age (estimated by tooth wear) and month of capture. Relative and seasonal growth were also studied. No statistical difference in body size was detected between sexes. The specimens showed highest growth rate up to about fourteen weeks of age. Afterwards, most of the variations detected in body length and especially in weight were basically related to sexual stage. Specimens born in the first litters of the year grew faster than those born at the end.

Departamento de Biología Animal (Vertebrados), Facultad de Biología, Universidad de Barcelona, Avda. Diagonal 645, 08028-Barcelona, Spain.
\end{abstract}

Key words: somatometry, relative growth, Crocidura russula, Spain

\section{Introduction}

Seasonal and age changes in body size during post-natal life have been extensively studied in Soricidae, especially in relation to the winter depression (Dehnel's phenomenon), which some species of the genus Sorex show as an adaptive process to living in polar and circumpolar regions (see Pucek 1970). In contrast, representatives of Crocidura, living in more southern areas, do not show such adaptive changes. Therefore, most of the studies on body size variations in this genus have been restricted to ontogenetic and early post-natal development (Fons 1972, Hellwing 1973, Vogel 1973, Gründwald and Möhrens 1974, Dippenaar 1979, Watson and Watson 1986). The white-toothed shrew Crocidura russula (Hermann, 1780) is widely distributed in the Iberian Peninsula (Niethammer and Krapp 1990). In previous studies, the population structure (López-Fuster 1984/85) and the reproductive characteristics (López-Fuster et al. 1985) of the species in northeastern Spain (Ebro Delta) were analysed. The breeding season of this population extends from February to September, with a notable decrease in sexual activity from August onwards. Because of the scant information available on the somatic growth of this species and to determine the possible effect that the reproductive cycle can exert on body size, we report some data about the variation 
in body measurements of C. russula from the Ebro Delta, according to sex, relative age and month of capture.

\section{Material and methods}

The sample analysed consists of 302 specimens ( 153 males, 149 females) captured between 1980 and 1982 in the Ebro Delta (northeastern Spain). The relative age of the specimens (classes I to V) was established using the criteria proposed by Gomez and Sans-Coma (1976) and Vesmanis and Vesmanis (1979), based on the height of the metaconid of the lower first molar (HM, in mm), and the tooth wear respectively.

Taking into account the characteristics of the reproductive cycle and the population structure of the species in the Ebro Delta, the following intervals of age were established (Lopez-Fuster 1983): class I: $0-6$ weeks, class II: $6-14$ weeks, class III: from 14 weeks to $8-9$ months, class IV: from $8-9$ to $13-14$ months, class V: from $13-14$ to $17-18$ months, with a maximum age in favourable conditions of $22-23$ months. Due to the great intraspecific variation in the teeth size of $C$. russula (Kahmann and Vesmanis 1974), these age intervals have a local application. Animals captured during the first year of their life are called first-year specimens; those aged over one year on capture are referred to as second-year specimens.

After trapping, the body weight (BW, in g) of the specimens was taken by a "Pesola" spring-scale (capacities of 10 or $30 \mathrm{~g}$ ). In pregnant females the weight of the embryos was subtracted. Likewise, the following measurements (in $\mathrm{mm}$ ) were considered (see Niethammer and Krapp 1990): head and body length (HBL), tail length (TL), hind foot length (HFL) and ear length (EL).

The variation percentages between the means of consecutive age classes were calculated by the formula (Ventura 1990): VP $=\left[\left(\bar{x}_{i}+1-\bar{x}_{i}\right) 100\right] / \bar{x}_{i}$ : where $\bar{x}_{i}$ and $\bar{x}_{i}+1$ are the averages corresponding to the age classes considered. The significance of the differences between two sample means was calculated by the Student's $t$-test (Sokal and Rohlf 1981).

The logarithmic transformation of the allometric formula $y=a x^{b}$ (Huxley 1932) yields a linear relation between $x$ and $y$, the scale invariant $\log y=\log a+b \log x$. Taking into account the criteria mentioned by Ricker (1973), regressions were calculated by model II or geometrical mean method (Sokal and Rohlf 1981). The significance of the differences between two regression coefficients was determined by comparing their confidence intervals at $95 \%$. Data were processed by a special program written by C. Viladiu (Department of Animal Biology, University of Barcelona).

The growth patterns of the specimens of the early and later litters were determined by dividing the sample studied into two groups formed by individuals of classes I - III. Animals of classes IV and $\mathrm{V}$ were rejected because of the difficulty of establishing their exact time of birth. The first group (March - August), constituted of specimens born in the first litters of the breeding season, is the following: class I: March (1 male), April ( 1 male, 2 females), May ( 3 females); class II: April (9 males), May (9 males, 7 females); class III: May (1 male), June (2 females), July (2 females), August ( 3 males, 2 females). The second group (July - February) was formed by specimens born at the end of the reproductive cycle: class I: July ( 1 male, 1 female), August ( 3 males, 1 female); class II: September (4 males, 7 females), October ( 3 males, 3 females), November ( 1 male, 1 female); class III: January (6 males, 7 females), February (9 males, 4 females).

\section{Results and discussion}

\section{Somatometry according to sex and relative age}

The somatic values according to relative age are shown in Table 1. Statistical comparison of the means in males and females for each age class reveals a noticeable biometric homogenity between sexes. The Student's $t$-test shows 
Table 1. Body and tooth measurements in C. russula, according to relative age (classes I - V). For abbreviations see text.

\begin{tabular}{|c|c|c|c|c|c|c|c|}
\hline \multicolumn{2}{|c|}{ Age class } & \multirow{2}{*}{$\begin{array}{l}\text { HBL } \\
17\end{array}$} & \multirow{2}{*}{$\frac{\mathrm{TL}}{17}$} & \multirow{2}{*}{$\begin{array}{l}\text { HFL } \\
14\end{array}$} & \multirow{2}{*}{$\frac{\text { EL }}{13}$} & \multirow{2}{*}{$\frac{\text { BW }}{17}$} & \multirow{2}{*}{$\begin{array}{l}\mathrm{HM} \\
17\end{array}$} \\
\hline I & $\mathrm{n}$ & & & & & & \\
\hline & $\bar{x}$ & 65.82 & 39.53 & 11.57 & 8.38 & 6.33 & 0.519 \\
\hline & SD & 4.273 & 2.304 & 0.457 & 0.560 & 0.543 & 0.017 \\
\hline & $\min$ & 58.0 & 34.0 & 10.5 & 8.0 & 4.7 & 0.484 \\
\hline & $\max$ & 73.5 & 42.0 & 12.0 & 10.0 & 7.2 & 0.549 \\
\hline \multirow[t]{5}{*}{ II } & $\mathrm{n}$ & 76 & 77 & 63 & 68 & 77 & 78 \\
\hline & $\bar{x}$ & 72.35 & 41.06 & 11.97 & 8.67 & 8.46 & 0.478 \\
\hline & SD & 3.435 & 2.287 & 0.366 & 0.450 & 0.938 & 0.030 \\
\hline & $\min$ & 63.5 & 35.0 & 11.0 & 7.0 & 7.1 & 0.420 \\
\hline & $\max$ & 82.5 & 47.0 & 13.0 & 9.5 & 11.5 & 0.549 \\
\hline \multirow[t]{5}{*}{ III } & $\mathrm{n}$ & 94 & 97 & 103 & 96 & 99 & 102 \\
\hline & $\bar{x}$ & 73.33 & 41.08 & 12.07 & 8.89 & 8.97 & 0.394 \\
\hline & SD & 3.416 & 2.270 & 0.369 & 0.484 & 0.855 & 0.036 \\
\hline & $\min$ & 63.5 & 35.5 & 11.0 & 7.5 & 7.3 & 0.323 \\
\hline & $\max$ & 82.5 & 47.0 & 13.0 & 10.0 & 11.5 & 0.452 \\
\hline \multirow[t]{5}{*}{ IV } & $\mathrm{n}$ & 84 & 86 & 78 & 80 & 87 & 87 \\
\hline & $\bar{x}$ & 75.05 & 40.96 & 12.15 & 9.01 & 9.53 & 0.248 \\
\hline & SD & 3.317 & 2.615 & 0.519 & 0.358 & 1.083 & 0.051 \\
\hline & $\min$ & 66.5 & 35.0 & 11.0 & 8.0 & 7.1 & 0.161 \\
\hline & $\max$ & 84.0 & 49.0 & 15.0 & 9.5 & 12.5 & 0.323 \\
\hline \multirow[t]{5}{*}{$\mathrm{V}$} & $\mathrm{n}$ & 15 & 15 & 14 & 14 & 15 & 16 \\
\hline & $\bar{x}$ & 77.20 & 40.47 & 12.07 & 9.11 & 10.66 & 0.120 \\
\hline & $\mathrm{SD}$ & 3.978 & 2.598 & 0.319 & 0.686 & 1.271 & 0.052 \\
\hline & $\min$ & 70.5 & 34.0 & 11.5 & 8.0 & 7.9 & 0.032 \\
\hline & $\max$ & 84.5 & 45.0 & 12.5 & 10.5 & 12.8 & 0.226 \\
\hline
\end{tabular}

Table 2. Variation percentages between the body size means of consecutive age classes in C. russula. For abbreviations see text.

\begin{tabular}{lrrrrr}
\hline $\begin{array}{c}\text { Age } \\
\text { intervals }\end{array}$ & HBL & TL & HFL & EL & \multicolumn{1}{c}{ BW } \\
\hline I - II & 9.92 & 3.87 & 3.46 & 3.46 & 33.65 \\
II - III & 1.35 & 0.05 & 0.83 & 2.54 & 6.03 \\
III - IV & 2.34 & -0.29 & 0.66 & 1.35 & 6.24 \\
IV - V & 2.86 & -1.20 & -0.66 & 1.11 & 11.86 \\
\hline
\end{tabular}

significant differences only in HBL in class I (males: $\mathrm{n}=8, \bar{x}=63.44, \mathrm{SD}=3.75$; females: $\mathrm{n}=9, \bar{x}=67.94, \mathrm{SD}=3.52 ; t=2.5518, p<0.05)$ and in BW in classes II (males: $\mathrm{n}=40, \bar{x}=8.68, \mathrm{SD}=1.04$; females: $\mathrm{n}=37, \bar{x}=8.23, \mathrm{SD}=0.74 ; t=$ 
Table 3. Variation of HBL in C. russula according to relative age (classes I - V) and month of capture. The broken line separates the first (on the left) and second (on the right) year specimens.

\begin{tabular}{|c|c|c|c|c|c|c|}
\hline Month & & I & II & III & IV & V \\
\hline March & $\begin{array}{l}\mathrm{n} \\
\bar{x} \\
\mathrm{SD} \\
\mathrm{OR}\end{array}$ & $\begin{array}{l}1 \\
61.00 \\
- \\
-\end{array}$ & $\begin{array}{l}- \\
- \\
-\end{array}$ & $\begin{array}{l}3 \\
77.83 \\
2.461 \\
75.0-81.0\end{array}$ & $\begin{array}{l}9 \\
76.50 \\
1.269 \\
74.0-79.0\end{array}$ & $\begin{array}{l}- \\
- \\
-\end{array}$ \\
\hline April & $\begin{array}{l}\frac{\mathrm{n}}{\bar{x}} \\
\mathrm{SD} \\
\mathrm{OR}\end{array}$ & $\begin{array}{l}3 \\
65.00 \\
1.225 \\
63.5-66.5\end{array}$ & $\begin{array}{l}9 \\
74.33 \\
2.297 \\
70.5-78.0\end{array}$ & $\begin{array}{l}3 \\
78.50 \\
1.779 \\
76.0-80.0 \\
\end{array}$ & $\begin{array}{l}12 \\
77.92 \\
2.613 \\
74.0-84.0\end{array}$ & $\begin{array}{l}4 \\
79.25 \\
1.920 \\
77.0-82.0\end{array}$ \\
\hline May & $\begin{array}{l}\mathrm{n} \\
\bar{x} \\
\mathrm{SD} \\
\mathrm{OR}\end{array}$ & $\begin{array}{l}3 \\
72.33 \\
1.027 \\
71.0-73.5\end{array}$ & $\begin{array}{l}16 \\
74.03 \\
3.271 \\
68.5-82.5\end{array}$ & $\begin{array}{l}1 \\
79.00 \\
- \\
-\end{array}$ & $\begin{array}{l}13 \\
76.42 \\
2.217 \\
73.0-80.0\end{array}$ & $\begin{array}{l}2 \\
84.00 \\
0.500 \\
83.5-84.5\end{array}$ \\
\hline June & $\begin{array}{l}\mathrm{n} \\
\bar{x} \\
\mathrm{SD} \\
\mathrm{OR}\end{array}$ & $\begin{array}{l}4 \\
63.62 \\
3.380 \\
58.0-65.0\end{array}$ & $\begin{array}{l}12 \\
71.04 \\
1.435 \\
69.0-74.0\end{array}$ & $\begin{array}{l}2 \\
76.50 \\
3.500 \\
73.0-80.0\end{array}$ & $\begin{array}{l}3 \\
79.00 \\
1.779 \\
76.5-80.5\end{array}$ & $\begin{array}{l}2 \\
75.25 \\
4.25 \\
71.0-79.5\end{array}$ \\
\hline July & $\begin{array}{l}\frac{\mathrm{n}}{\bar{x}} \\
\mathrm{SD} \\
\mathrm{OR}\end{array}$ & $\begin{array}{l}2 \\
68.7 \\
0.750 \\
68.0-69.5\end{array}$ & $\begin{array}{l}11 \\
71.68 \\
3.569 \\
68.0-79.0\end{array}$ & $\begin{array}{l}2 \\
75.00 \\
2.000 \\
73.0-77.0\end{array}$ & $\begin{array}{l}3 \\
76.00 \\
2.160 \\
73.0-78.0\end{array}$ & $\begin{array}{l}2 \\
75.50 \\
0.500 \\
75.0-76.0\end{array}$ \\
\hline August & $\begin{array}{l}\frac{\mathrm{n}}{\bar{x}} \\
\mathrm{SD} \\
\mathrm{OR}\end{array}$ & $\begin{array}{l}4 \\
63.50 \\
3.373 \\
60.0-68.0\end{array}$ & $\begin{array}{l}10 \\
70.00 \\
4.561 \\
63.5-78.0\end{array}$ & $\begin{array}{l}3 \\
74.50 \\
4.601 \\
68.0-78.0\end{array}$ & $\begin{array}{l}2 \\
76.75 \\
0.750 \\
76.0-77.5\end{array}$ & $\begin{array}{l}1 \\
70.50 \\
- \\
-\end{array}$ \\
\hline September & $\begin{array}{l}\mathrm{n} \\
\bar{x} \\
\mathrm{SD} \\
\mathrm{OR}\end{array}$ & $\begin{array}{l}- \\
- \\
-\end{array}$ & $\begin{array}{l}10 \\
72.80 \\
3.348 \\
67.5-79.0\end{array}$ & $\begin{array}{l}11 \\
72.18 \\
4.422 \\
63.5-82.5\end{array}$ & $\begin{array}{l}1 \\
77.50 \\
- \\
-\end{array}$ & $\begin{array}{l}1 \\
76.00 \\
- \\
-\end{array}$ \\
\hline October & $\begin{array}{l}\frac{\mathrm{n}}{\bar{x}} \\
\mathrm{SD} \\
\mathrm{OR}\end{array}$ & $\begin{array}{l}- \\
- \\
-\end{array}$ & $\begin{array}{l}6 \\
71.50 \\
1.384 \\
68.5-72.5\end{array}$ & $\begin{array}{l}12 \\
71.46 \\
1.547 \\
69.5-73.5\end{array}$ & $\begin{array}{l}- \\
- \\
- \\
-\end{array}$ & $\begin{array}{l}- \\
- \\
-\end{array}$ \\
\hline November & $\begin{array}{l}\mathrm{n} \\
\bar{x} \\
\mathrm{SD} \\
\text { OR }\end{array}$ & $\begin{array}{l}- \\
- \\
-\end{array}$ & $\begin{array}{l}2 \\
73.75 \\
2.250 \\
71.5-76.0\end{array}$ & $\begin{array}{l}16 \\
72.50 \\
2.023 \\
70.0-76.5\end{array}$ & $\begin{array}{l}1 \\
69.50 \\
- \\
-\end{array}$ & $\begin{array}{l}1 \\
75.00 \\
- \\
-\end{array}$ \\
\hline December & $\begin{array}{l}\mathbf{n} \\
\bar{x} \\
\mathrm{SD} \\
\mathrm{OR}\end{array}$ & $\begin{array}{l}- \\
- \\
-\end{array}$ & $\begin{array}{l}- \\
- \\
-\end{array}$ & $\begin{array}{l}15 \\
72.57 \\
2.522 \\
69.5-77.0\end{array}$ & $\begin{array}{l}8 \\
72.31 \\
2.936 \\
67.0-77.5\end{array}$ & $\begin{array}{c}1 \\
74.00 \\
- \\
-\end{array}$ \\
\hline January & $\begin{array}{l}\mathrm{n} \\
\bar{x} \\
\mathrm{SD} \\
\mathrm{OR}\end{array}$ & $\begin{array}{l}- \\
- \\
-\end{array}$ & $\begin{array}{l}- \\
- \\
-\end{array}$ & $\begin{array}{l}12 \\
72.12 \\
2.732 \\
68.0-76.5\end{array}$ & $\begin{array}{l}15 \\
71.37 \\
2.729 \\
66.5-76.5\end{array}$ & $\begin{array}{l}1 \\
76.00 \\
- \\
- \\
\end{array}$ \\
\hline February & $\begin{array}{l}\frac{\mathrm{n}}{\bar{x}} \\
\mathrm{SD} \\
\mathrm{OR}\end{array}$ & $\begin{array}{l}- \\
- \\
-\end{array}$ & $\begin{array}{l}- \\
- \\
-\end{array}$ & $\begin{array}{l}14 \\
75.11 \\
3.174 \\
71.0-81.0\end{array}$ & $\begin{array}{l}17 \\
74.85 \\
1.885 \\
71.0-78.5\end{array}$ & $\begin{array}{l}- \\
- \\
-\end{array}$ \\
\hline
\end{tabular}


Table 4. Variation of BW in C. russula according to relative age (classes I - V) and month of capture. The broken line separates the first (on the left) and second (on the right) year specimens.

\begin{tabular}{|c|c|c|c|c|c|c|}
\hline Month & & I & II & III & IV & $\mathrm{V}$ \\
\hline March & $\begin{array}{l}\mathrm{n} \\
\bar{x} \\
\mathrm{SD} \\
\mathrm{OR}\end{array}$ & $\begin{array}{l}1 \\
4.70 \\
- \\
-\end{array}$ & $\begin{array}{l}- \\
- \\
-\end{array}$ & $\begin{array}{l}3 \\
9.80 \\
1.257 \\
8.5-11.5\end{array}$ & $\begin{array}{l}10 \\
9.42 \\
1.013 \\
8.0-11.5\end{array}$ & $\begin{array}{l}- \\
- \\
-\end{array}$ \\
\hline April & $\begin{array}{l}\mathrm{n} \\
\bar{x} \\
\mathrm{SD} \\
\mathrm{OR}\end{array}$ & $\begin{array}{l}3 \\
6.13 \\
0.330 \\
5.7-6.5\end{array}$ & $\begin{array}{l}9 \\
8.28 \\
0.816 \\
7.2-9.5\end{array}$ & $\begin{array}{c}3 \\
10.63 \\
0.125 \\
10.5-10.8\end{array}$ & $\begin{array}{l}12 \\
10.52 \\
0.970 \\
9.0-12.5\end{array}$ & $\begin{array}{l}5 \\
10.68 \\
1.455 \\
9.0-12.8\end{array}$ \\
\hline May & $\begin{array}{l}\mathrm{n} \\
\bar{x} \\
\mathrm{SD} \\
\mathrm{OR}\end{array}$ & $\begin{array}{l}3 \\
6.40 \\
0.163 \\
6.2-6.6\end{array}$ & $\begin{array}{l}16 \\
8.70 \\
1.106 \\
7.2-11.5\end{array}$ & $\begin{array}{l}1 \\
9.40 \\
- \\
-\end{array}$ & $\begin{array}{l}13 \\
10.08 \\
0.686 \\
8.9-11.0\end{array}$ & $\begin{array}{l}2 \\
10.50 \\
0.500 \\
10.0-11.0\end{array}$ \\
\hline June & $\begin{array}{l}\mathrm{n} \\
\bar{x} \\
\mathrm{SD} \\
\mathrm{OR}\end{array}$ & $\begin{array}{l}4 \\
6.57 \\
0.349 \\
6.1-7.0\end{array}$ & $\begin{array}{l}12 \\
9.09 \\
0.770 \\
8.0-10.5\end{array}$ & $\begin{array}{l}2 \\
10.25 \\
0.250 \\
10.0-10.5\end{array}$ & $\begin{array}{l}3 \\
10.27 \\
0.403 \\
9.7-10.6\end{array}$ & $\begin{array}{c}1 \\
12.00 \\
- \\
-\end{array}$ \\
\hline July & $\begin{array}{l}\mathrm{n} \\
\bar{x} \\
\mathrm{SD} \\
\mathrm{OR}\end{array}$ & $\begin{array}{l}2 \\
6.90 \\
0.300 \\
6.6-7.2\end{array}$ & $\begin{array}{l}11 \\
8.19 \\
0.841 \\
7.1-9.9\end{array}$ & $\begin{array}{l}2 \\
9.30 \\
1.400 \\
7.9-10.7\end{array}$ & $\begin{array}{l}3 \\
9.67 \\
0.805 \\
9.0-10.8\end{array}$ & $\begin{array}{l}2 \\
11.55 \\
0.750 \\
10.8-12.3\end{array}$ \\
\hline August & $\begin{array}{l}\frac{\mathrm{n}}{\bar{x}} \\
\mathrm{SD} \\
\mathrm{OR}\end{array}$ & $\begin{array}{l}4 \\
6.30 \\
0.255 \\
6.0-6.7\end{array}$ & $\begin{array}{l}11 \\
7.81 \\
0.382 \\
7.3-8.6\end{array}$ & $\begin{array}{l}5 \\
8.26 \\
0.550 \\
7.6-9.2\end{array}$ & $\begin{array}{l}2 \\
10.85 \\
1.150 \\
9.7-12.0\end{array}$ & $\begin{array}{l}1 \\
7.90 \\
- \\
-\end{array}$ \\
\hline September & $\begin{array}{l}\mathrm{n} \\
\bar{x} \\
\mathrm{SD} \\
\mathrm{OR}\end{array}$ & $\begin{array}{l}- \\
- \\
-\end{array}$ & $\begin{array}{l}10 \\
8.31 \\
0.749 \\
7.2-9.4\end{array}$ & $\begin{array}{l}12 \\
8.72 \\
0.521 \\
8.0-9.8\end{array}$ & $\begin{array}{l}2 \\
9.95 \\
0.150 \\
9.8-10.1\end{array}$ & $\begin{array}{l}1 \\
11.20 \\
- \\
-\end{array}$ \\
\hline October & $\begin{array}{l}\mathrm{n} \\
\bar{x} \\
\mathrm{SD} \\
\mathrm{OR}\end{array}$ & $\begin{array}{l}- \\
- \\
-\end{array}$ & $\begin{array}{l}6 \\
8.70 \\
0.920 \\
7.3-10.2\end{array}$ & $\begin{array}{l}12 \\
8.76 \\
0.613 \\
7.5-9.7\end{array}$ & $\begin{array}{l}- \\
- \\
-\end{array}$ & $\begin{array}{l}- \\
- \\
-\end{array}$ \\
\hline November & $\begin{array}{l}\mathrm{n} \\
\bar{x} \\
\mathrm{SD} \\
\mathrm{OR}\end{array}$ & $\begin{array}{l}- \\
- \\
-\end{array}$ & $\begin{array}{l}2 \\
8.70 \\
1.20 \\
7.5-9.9\end{array}$ & $\begin{array}{l}16 \\
8.75 \\
0.840 \\
7.3-10.5\end{array}$ & $\begin{array}{l}1 \\
7.10 \\
- \\
-\end{array}$ & $\begin{array}{c}1 \\
10.25 \\
- \\
-\end{array}$ \\
\hline December & $\begin{array}{l}\mathrm{n} \\
\bar{x} \\
\mathrm{SD} \\
\mathrm{OR}\end{array}$ & $\begin{array}{l}- \\
- \\
-\end{array}$ & $\begin{array}{l}- \\
\overline{-} \\
-\end{array}$ & $\begin{array}{l}16 \\
8.64 \\
0.466 \\
7.9-9.4\end{array}$ & $\begin{array}{l}9 \\
8.62 \\
0.632 \\
7.6-9.6\end{array}$ & $\begin{array}{c}1 \\
10.00 \\
- \\
-\end{array}$ \\
\hline January & $\begin{array}{l}\mathrm{n} \\
\bar{x} \\
\mathrm{SD} \\
\mathrm{OR}\end{array}$ & - & $\begin{array}{l}- \\
- \\
-\end{array}$ & $\begin{array}{l}13 \\
9.18 \\
0.677 \\
7.9-10.0\end{array}$ & $\begin{array}{l}15 \\
9.01 \\
0.993 \\
7.2-11.0\end{array}$ & $\begin{array}{c}1 \\
11.0 \\
- \\
- \\
\end{array}$ \\
\hline February & $\begin{array}{l}\mathrm{n} \\
\bar{x} \\
\mathrm{SD} \\
\mathrm{OR} \\
\end{array}$ & $\begin{array}{l}- \\
\text { - } \\
\text { - }\end{array}$ & $\begin{array}{l}- \\
- \\
-\end{array}$ & $\begin{array}{l}14 \\
9.24 \\
0.856 \\
7.9-10.5 \\
\end{array}$ & $\begin{array}{l}17 \\
9.18 \\
0.759 \\
8.1-11.0\end{array}$ & $\begin{array}{l}- \\
- \\
-\end{array}$ \\
\hline
\end{tabular}


$2.2, p<0.05$ ) and $\mathrm{V}$ (males: $\mathrm{n}=4, \bar{x}=9.52$, $\mathrm{SD}=1.22$; females: $\mathrm{n}=11, \bar{x}=11.07$, $\mathrm{SD}=1.01 ; t=2.4993, p<0.05)$. However, no significant difference was detected when samples were made homogeneous in number of specimens per sex and month of capture. Thereby, the difference observed is not attributed to sexual dimorphism in this population.

These results agree with those quoted by Sans-Coma et al. (1976) for C. $r$. russula from Bonn (Germany). However, these authors find sexual dimorphism in HBL and BW in specimens from the Meda Gran island (Gerona, Spain) and various localities of mainland Catalonia. According to these authors, females show significantly lower mean values than males in both parameters. Nevertheless, because of the diverse origin of the specimens and the heterogenous monthly composition of the samples, the sexual differences detected in these cases are probably at random and do not express a real phenomenon.

Fons (1972) mentioned that in 950 specimens from Banyuls-sur-mer (France) the highest extreme values of HBL and BW correspond to the males. However this author does not refer the averages of these parameters and it is not possible to evaluate the significance of the differences observed between sexes. In general, the extreme values of HBL obtained in C. russula from the Ebro Delta are similar to those reported by Fons (1972); for BW, the maximal values observed are higher than those quoted by this author.

\section{Relative growth}

Because of the biometrical similarity between sexes, relative growth was evaluated jointly in males and females. The variation percentages of the means between consecutive age classes (Table 2) show that all parameters analysed have the greatest growth rates at the interval I - II, up to about fourteen weeks of age. The relatively high growth that EL still exhibits at the next age interval is also outstanding. Likewise, BW also shows a noticeable increase at the interval IV $\mathrm{V}$, due to the heterogenous composition of the samples of these age classes. So, while class $\mathrm{V}$ is formed by second-year specimens, most of them sexually active and showing high body weights, class IV shows a high percentage of first-year specimens, which have not reached sexual maturity.

\section{Annual variation in head-body length and body weight}

In Table 3 the annual variation of HBL according to relative age is shown. In spite of the low number of specimens in the monthly samples of class I, it seems that the mean of this parameter shows a gradual increase from March to May. From June onwards, this parameter fluctuates because of the progressive appearance of juveniles in the population, coming from the later litters of the breeding season (López-Fuster et al. 1985). Specimens of class II show the largest mean values of the year in April and May; in these months most of these specimens are sexually active (López-Fuster et al. 1985). From June onwards, the average of 
HBL shows monthly oscillations because of the gradual incorporation of first-year specimens, which do not generally attain sexual maturity in the year of their birth.

The first specimen of the year of class III appears at the end of May (26.5.). Its body dimensions are close to those of the second-year specimens of classes IV and V. From June to October the average of HBL decreases significantly $(t=$ $3.6805, p<0.01$ ) because the progressive incorporation to class III of the specimens of the preceding class. From October, when the population is basically constituted by first-year specimens, to January, the mean values of HBL show no significant variations. In February, the average of HBL in classes III and IV increases significantly (class III: $t=2.5508, p<0.02$; class IV: $t=4.239, p<0.001$ ) because the adult specimens which make up the population begin sexual activity. In the second-year individuals of classes IV and V, the mean values of HBL remain high during the whole reproductive cycle. Except for one specimen from class V captured in August (HBL $=70.5 \mathrm{~mm}$ ), adults do not show a marked reduction in body size once the reproductive period is over.

The average of BW shows monthly fluctuations in the different age classes (Table 4), as occurs in HBL. In the specimens of class I, the mean of BW seems to increase gradually from March to June, diminishing slightly in August. From April to June individuals from classes II and III exhibit high means of BW, basically due to the acquisition of the sexual maturity of the specimens born in the first litters of the year (see López-Fuster 1984/85). In July and August this parameter diminishes significantly (differences between June - August: class II: $t=4.974, p<0.001$; class III: $t=4.7148, p<0.001$ ); most of the specimens which are passing to classes II and III at this time do not attain sexual maturity until the following year. From September to January, BW undergoes a new, but not significant, increase because the incorporation of juveniles to the population ceases, since the reproductive cycle is over.

Animals from classes III and IV which are wintering show a significant increase in the means of BW from January onwards (class III, differences between January - April: $t=3.6016, p<0.01$; class IV, differences between January August: $t=2.434, p<0.05$ ). The averages of this parameter remain high all through the reproductive season. The results obtained reveal that senile specimens (class V) are not subject to a body weight reduction.

\section{Seasonal growth}

The variation of HBL and BW respect to the relative age in the specimens coming from the first (sample March - August) and the later litters (sample July - February) of the reproductive cycle were analysed (Table 5). Statistical comparison of the sample means does not reveal significant differences in either parameter, although the highest mean values of the HBL correspond to the specimens from March - August. The high values of BW in the specimens of class III from July - February should be emphasized (Table 5). This age class is exclusively composed by individuals from January and February that initiate their 
Table 5. Variation in head-body lenght (HBL) and body weight (BW) in specimens of $C$. russula from the early (M-A: March August) and later (J - F: July - February) litters of the year.

\begin{tabular}{|c|c|c|c|c|c|}
\hline \multirow{2}{*}{\multicolumn{2}{|c|}{ Age class }} & \multicolumn{2}{|c|}{ HBL } & \multicolumn{2}{|c|}{ BW } \\
\hline & & $\mathrm{M}-\mathrm{A}$ & $J-F$ & $\mathrm{M}-\mathrm{A}$ & $J-F$ \\
\hline \multirow[t]{5}{*}{ I } & $\mathrm{n}$ & 6 & 6 & 6 & 6 \\
\hline & $\bar{x}$ & 68.67 & 65.25 & 6.27 & 6.50 \\
\hline & SD & 3.837 & 3.728 & 0.292 & 0.391 \\
\hline & $\min$ & 63.5 & 60.0 & 5.7 & 6.0 \\
\hline & $\max$ & 73.5 & 69.5 & 6.6 & 7.2 \\
\hline \multirow[t]{5}{*}{ II } & $\mathrm{n}$ & 25 & 18 & 25 & 18 \\
\hline & $\bar{x}$ & 74.14 & 72.47 & 8.55 & 8.48 \\
\hline & SD & 2.961 & 2.826 & 1.031 & 0.890 \\
\hline & $\min$ & 68.5 & 67.5 & 7.2 & 7.2 \\
\hline & $\max$ & 82.5 & 79.0 & 11.5 & 10.2 \\
\hline \multirow[t]{5}{*}{ III } & $\mathbf{n}$ & 8 & 25 & 10 & 26 \\
\hline & $\bar{x}$ & 75.69 & 73.88 & 8.98 & 9.25 \\
\hline & $\mathrm{SD}$ & 3.766 & 3.439 & 1.084 & 0.800 \\
\hline & $\min$ & 68.0 & 68.0 & 7.6 & 7.9 \\
\hline & $\max$ & 80.0 & 81.0 & 10.7 & 10.5 \\
\hline
\end{tabular}
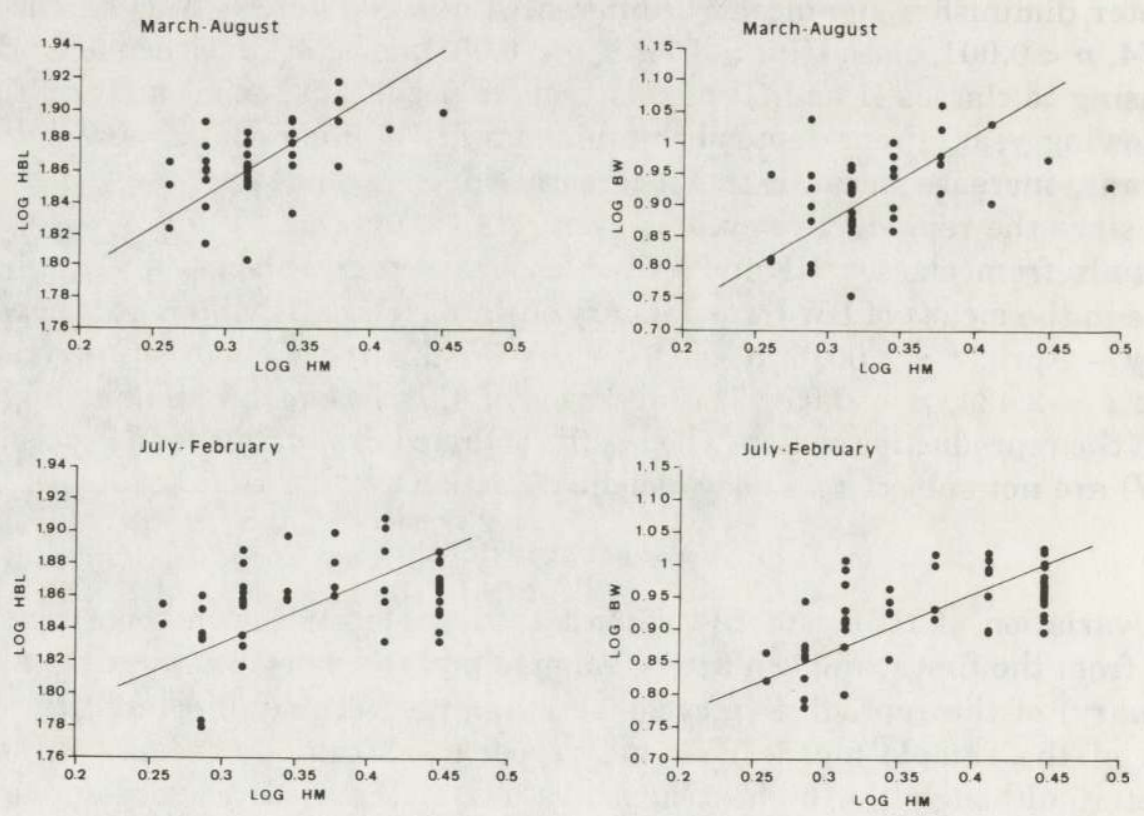

Fig. 1. Relationship between head-body length (HBL) and body weight (BW) against the height of the metaconid of the $\mathrm{M}_{1}(\mathrm{HM})$ in specimens of $C$. russula from the early (March - August) and later (July - February) litters of the year. For regression equations see text. 
reproductive activity at this time. Therefore, these specimens undergo a noticiable increase in BW.

HBL and BW have been correlated with HM, taken as an age estimator, to determine the growth patterns of these parameters in each period considered (Fig. 1). The correlation coefficients obtained are significant in all cases (HBL: March - August: $\mathrm{n}=38, r=0.555, p<0.001$; July - February: $\mathrm{n}=49, r=0.387, p<$ 0.005 . BW: March - August: $\mathrm{n}=40, r=0.4502, p<0.005$; July - February: $\mathrm{n}=$ $50, r=0.5734, p<0.001$ ).

The slope of the regression line $(b)$ for HBL in March - August $(\log \mathrm{HBL}=1.68$ $+0.5724 \log \mathrm{HM}, \mathrm{eb}=0.1604)$ is significantly higher than that obtained in July - February $(\log$ HBL $=1.7128+0.3916 \log \mathrm{HM}$, eb $=0.1053)$. Nevertheles, both slopes reveal negative allometry. For BW the difference between both regression coefficients is also significant (March - August: $\log \mathrm{BW}=0.4521+1.4 \log \mathrm{HM}$, $\mathrm{eb}=0.4099$; July - February: $\log \mathrm{BW}=0.5796+0.9451 \log \mathrm{HM}, \mathrm{eb}=0.2235)$. In March - August there is positive allometry favourable to BW, while in July February, the slope of BW against HM does not differ significantly from the isometric condition. Considering the regression coefficient as a growth rate, we observe that specimens born at the beginning of the reproductive season grow faster than those coming from the later litters of the annual cycle. These different seasonal growth patterns, together with the degree of sexual maturity, could explain the monthly fluctuations in the means of HBL observed in specimens of class II from June onwards.

Acknowledgements: The authors wish to thank Prof. Dr. Valentín Sans-Coma (Málaga), and Prof. Dr. Joaquim Gosàlbez (Barcelona) for their helpful suggestions, and Robin Rycroft (Barcelona) for improving the English text.

\section{References}

Dippenaar N. J. 1979. Notes on the early post-natal development and behaviour of the tiny musk shrew Crocidura bicolor Bocage, 1889. (Insectivora: Soricidae). Mammalia 43: 84 - 91.

Fons R. 1972. La musaraigne musette. Crocidura russula (Hermann, 1780). Science et Nature 112: $23-28$.

Gómez I. and Sans-Coma V. 1976. Edad relativa de Crocidura russula en egagrópilas de Tyto alba en el nordeste ibérico. Misc. Zool. 3: 209-212.

Gründwald A. and Möhres F. P. 1974. Beobachtungen zur Jugendentwicklung und Karawanenbildung bei Weisszahnspitzmäusen (Soricidae-Crocidurinae). Z. Säugetierk. 39: 321 - 337.

Hellwing S. 1973. The postnatal development of the white-toothed shrew Crocidura russula monacha in captivity. Z. Säugetierk. 38: $257-270$.

Huxley J. 1932. Problems of relative growth. Methuen, London: 1-203.

Kahmann H. and Vesmanis I. 1974. Morphometrische Untersuchungen an Wimperspitzmäusen (Crocidura). 1. Die Gartenspitzmaus Crocidura suaveolens (Pallas, 1811) auf Menorca. Säugetierkdl. Mitt. 22: $313-324$.

López-Fuster M. J. 1983. Sobre los géneros Sorex Linnaeus, 1758, Suncus Ehrenberg, 1833 y Crocidura Wagler, 1832 (Insectivora, Soricidae) en el nordeste de la Peninsula Ibérica. Tesis Doctoral, Univ. de Barcelona: 1 - 338 . 
López-Fuster M. J. 1984/85. Population structure of Crocidura russula Hermann, 1780 (Insectivora, Mammalia) in the Ebro Delta (Catalonia, Spain) throughout the year. Säugetierkdl. Mitt. 32: $21-25$.

López-Fuster M. J., Gosàlbez J. and Sans-Coma V. 1985. Über die Fortpflanzung der Hausspitzmaus (Crocidura russula Hermann, 1780) im Ebro-Delta (Katalonien, Spanien). Z. Saügetierk. 50: 1-6.

Niethammer J. and Krapp F. (eds) 1990. Handbuch der Säugetiere Europas. Band 3. Akademische Verlagsgesellschaft, Wiesbaden: $1-524$.

Pucek Z. 1970. Seasonal and age changes in shrews as an adaptive process. Symp. zool. Soc. Lond. 26: $189-207$.

Ricker W. E. 1973. Linear regressions in fishery research. J. Fish. Board Can. 30: $409-434$.

Sans-Coma V., Gómez I. and Gosàlbez J. 1976. Eine Untersuchungen über der Hausspitzmaus (Crocidura russula Hermann, 1780) auf der Insel Meda Grossa (Katalonien, Spanien). Säugetierkdl. Mitt. 24: $279-288$.

Sokal R. R. and Rohlf F. J. 1981. Biometry: the principles and practice of statistics in biological research. Second ed. Freeman and Company, San Francisco: 1-859.

Vesmanis I. and Vesmanis A. 1979. Ein Vorschlag zur einheitlichen Alterabstufung bei Wimperspitzmäusen (Mammalia: Insectivora: Crocidura). Bonn. zool. Beitr. 30: 7 - 13.

Ventura J. 1990. Datos biométricos sobre los huesos largos y la escápula de Arvicola sapidus Miller, 1908 (Rodentia, Arvicolidae). Bol. R. Soc. Esp. Hist. Nat. (Sec. Biol.) 86: 55 - 64.

Vogel P. 1973. Vergleichende Untersuchung zum Ontogenesemodus einheimischer Soriciden (Crocidura russula, Sorex araneus und Neomys fodiens). Revue suisse Zool. 79: 1201 - 1332.

Watson C. R. B. and Watson R. T. 1986. Observations on the postnatal development of the tiny musk shrew, Crocidura bicolor. S. Afr. J. Zool. 21: $352-354$.

Received 16 September 1992, accepted 31 December 1992. 